\title{
1 An operational approach for the designing of an energy integrated oxy-fuel CFB power plant
}

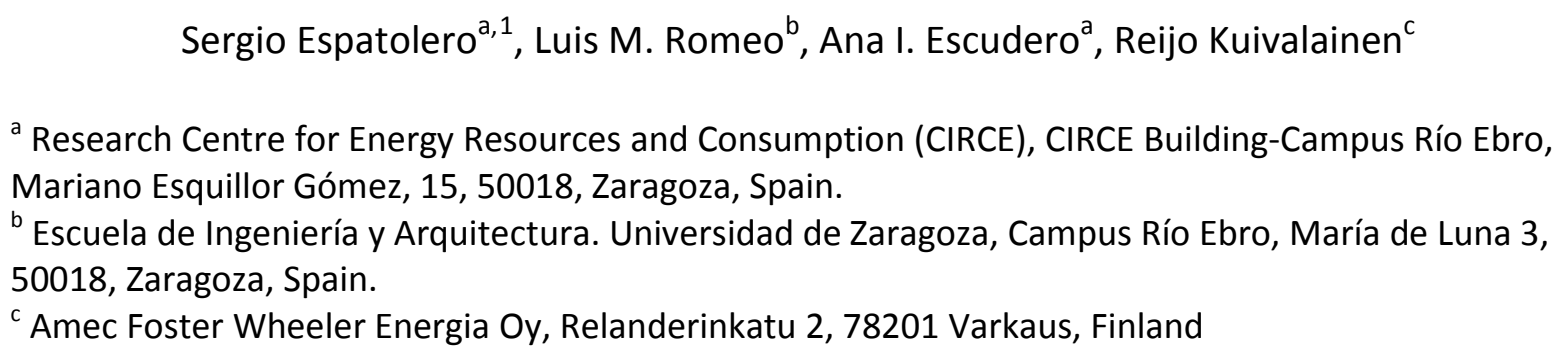

\begin{abstract}
Oxy-fuel combustion is one of the key alternatives for coal power production with near-zero $\mathrm{CO}_{2}$ emissions. Technology has been successfully proved in demonstration facilities and the next step is to improve its efficiency to facilitate the application to future commercial installations. The use of pure oxygen reduces the total volume of flue gases and concentrates $\mathrm{CO}_{2}$ at boiler outlet. Nevertheless, there is an important energy penalty and efficiency of the power plant substantially decreases around 10-12 efficiency points. Increasing the oxygen concentration in the boiler up to $40 \%$ is a recent proposal to raise boiler efficiency and it is also an interesting solution to overcome the energy penalties of the kind of CCS system.
\end{abstract}

Air separation unit (ASU) and compression and purification unit (CPU) are the main processes that reduce the efficiency. Heat integration results mandatory in order to improve the overall power plant efficiency by reducing the energy penalty. Many solutions have tried to show outstanding efficiency results but practical proposals are necessary to develop the technology. The use of flue gases waste energy to recycle flue gases heating up, oxygen preheating and increasing temperature of feedwater to steam cycle has been proposed to surpass the efficiency reduction. Nevertheless, care should be taken as potential problems would appear if only theoretical analysis is carried out.

This work deals with a suitable and flexible design to increase the overall efficiency of a second oxy-fuel combustion power plant working with high $\mathrm{O}_{2}$ concentration. Waste energy has been integrated avoiding any potential risk/damage into a new designed steam cycle. Finally, results are compared with a previously optimized power plant design without operational restrictions and just a slight reduction in power plant net efficiency (less than $1 \%)$ was observed between both concepts.

\footnotetext{
${ }^{1}$ Corresponding author: E-mail: sespato@fcirce.es Phone: +34 976 761863. Fax: +34 976732078.
} 


$\begin{array}{lll}41 & \text { Abbreviations } \\ 42 & \text { ASU } & \text { Air separation unit } \\ 43 & \text { CCS } & \text { Carbon capture and storage } \\ 44 & \text { CFB } & \text { Circulating fluidized bed } \\ 45 & \text { CPU } & \text { CO }_{2} \text { compression and purification unit } \\ 46 & \text { EHE } & \text { External heat exchanger } \\ 47 & \text { ESP } & \text { Electrostatic precipitator } \\ 48 & \text { FBHE } & \text { Fluidized bed heat exchanger } \\ 49 & \text { FG } & \text { Flue gas } \\ 50 & \text { FW } & \text { Feedwater } \\ 51 & \text { HEN } & \text { Heat exchanger network } \\ 52 & \text { HEX } & \text { Heat exchanger } \\ 53 & \text { HP } & \text { High pressure } \\ 54 & \text { LHV } & \text { Lower heating value } \\ 55 & \text { LP } & \text { Low pressure } \\ 56 & \text { MCR } & \text { Maximum continuous rating } \\ 57 & \text { PC } & \text { Pulverized coal } \\ 58 & \text { RFG } & \text { Recirculated flue gas } \\ 59 & \text { SCAH } & \text { Steam coil air heaters } \\ 60 & & \\ 50 & & \end{array}$

61 Keywords: oxy-fuel combustion, $\mathrm{CO}_{2}$ capture, heat integration, energy penalty, power plant 62 efficiency

63

64

65

\section{Introduction}

Oxy-fuel technology was firstly developed as an alternative to postcombustion and precombustion technologies for decarbonization of the pulverized coal-fired power plants. The combustion with pure oxygen reduces the volume of flue gases and increases the $\mathrm{CO}_{2}$ concentration at outlet, eliminating the $\mathrm{CO}_{2}$ separation stage and the associated energy requirements [1]. On the contrary, the necessity of an Air Separation Unit for $\mathrm{O}_{2}$ generation, penalizes the overall power plant net efficiency and increases the capital cost of the facility.

In the recent years, the attention has been paid to the circulating fluidized beds (CFB) due to their inherent advantages: better control of the boiler temperature, higher fuel flexibility and a remarkable reduction of pollutant emissions by low NOx generation and in situ desulphurisation [2,3]. Moreover, the use of CFB reduces the flue gas recirculation and the operational challenges that the movement of large volumes of gas implies. The circulation of 
solid particles that can be used as a heat sink or source in different part of the system facilitates the control and the difference of the temperature [4] causing also a reduction of energy penalty associated with oxy-fuel technology.

The application of CFB for oxy-fuel combustion comprises two concepts: the retrofit case consisting of an air-fired CFB boiler modified to operate with oxygen instead of air; and the new design case consisting of a specific new CFB designed to work with high oxygen concentrations $[5,2]$. The retrofit case has been widely studied in some pilot experiences that have analyzed the combustion performance, emission control and heat release in the boiler [6-9]. The case of new design using high oxygen concentration in the boiler input has been lately studied in the O2GEN project [10] and several works dealing with combustion $[11,12]$, emissions control [13] and specific features of these systems for heat absorption [14-16]. In any case, the use of high oxygen concentration in the oxidant entails the decrease of flue gas volume flow and hence, the reduction of the furnace cross section and the auxiliary power from fans.

Despite the different boiler design and configuration, these systems share a common characteristic, the necessity of an Air Separation Unit (ASU) and a Carbon Processing Unit (CPU). Although the latest developments, ASU is the main power consumer in an oxyfuel power plant. Values of $140 \mathrm{kWh} / \mathrm{t}_{\mathrm{O} 2}$ have been reported. These figures were achieved by using of waste heat internally in the process [17]. $\mathrm{CPU}$, including $\mathrm{CO}_{2}$ compression, is another important power consumer, around $7.7 \%$ of gross power is used in this equipment [18] and reduction of this value is more difficult than for ASU.

As other CCS options, the challenges of oxy-fuel combustion are the reduction of energy penalty and the increase of the efficiency of the process. In this case, the possibilities to overcome these challenges include: (i) improvements in the ASU and CPU; (ii) the optimization of the flue gas recycle; and (iii) the energy integration to use the residual heat from different parts of the system.

First studies quantified the penalty around 11-12 efficiency points [19-21]. For pulverized coal power plants efficiency improvement strategies have been focused on the flue gas recycle [22] comparing the differences between dry, semi-dry and wet recirculation to reduce the penalty to around 10 efficiency points [23] or designing optimum flue gas recycle process based on exergy analysis [24]. An exergy-based methodology was also proposed to assess the energy penalty of different first generation oxy-fired pulverized coal power plants [25]. Combining pinch analysis and exergy calculations, several process modifications were proposed to reduce the penalty of oxy-fuel pulverized coal (PC) power plants to 8.3 efficiency points. Other works proposed optimized system layouts with efficiency penalties of 9 points [26], 8.5 [27] or 7.7 [28].

For circulating fluidized bed it has been reported also a detailed analysis of flue gas recirculation with penalties of 8.8 points [4]. Around the same penalty was obtained by Gao et al. but they concluded that efficiency loss could be reduced by using optimized cryogenic ASU processes and a higher level of integration [22]. Later works, with integration and high oxygen concentration in the boiler and optimized ASU and CPU designs, reduce the penalty to 7.3 points [29] and to 7.26 points using the waste heat from ASU, CCS installation and flue 
124 gas in a lignite drying system [30]. In this case, the introduction of the drying installation has

125 a major impact on the growth in efficiency of the oxy-fuel installation but is feasible only for

126 high moisture fuels.

128 Simulation is a powerful tool to optimize the energy integration for minimizing the energy 129 penalty in CCS. Nevertheless it is evident that a full integration could mean less operation 130 flexibility in the power plant. New designs with high degree of integration promise higher efficiency performance and lower operating costs, but on the other hand can suppose new operating requirements and operability limitations.

This paper deals with some of these limitations proposing alternatives and analyzing the effect in efficiency reduction. Firstly, some general schemes for heat recovery from flue gases are presented and then, potential risks that could affect the operability of the system are stated. In order to overcome these limitations, some technical solutions are proposed defining a new feasible oxy-fuel CFB power plant concept from a practical and operational approach. Finally, the integrated oxy-fuel CFB power plant is modelled and results are compared with previous designs without operational restrictions.

\section{Key systems for waste energy recovery}

142 To obtain an optimized design we should consider the best solutions for the ASU, the CPU 143 and the CFB boiler arrangement. Then, different waste heat integration configurations for 144 the oxy-fuel power plant have to be proposed in order to increase the overall net electric efficiency and consequently to decrease the energy penalty.

Intersections among ASU, CPU and the flue gases from boiler are crucial to obtain good efficiency figures. Flue gases leaving the boiler at high temperature have an important energy content that must be used before being recirculated to accommodate boiler temperature and oxidant stream composition at boiler inlet.

Flue gases leaving the boiler may exchange energy with the steam cycle (low pressure (LP) or high pressure (HP) feedwater heat exchangers), oxygen preheating and recirculated flue gases (RFG). According to literature, which is mainly focused on PC applications of oxy-fuel technology, there is no oxygen preheating $\left(20{ }^{\circ} \mathrm{C}\right.$ at ASU outlet) as it is mixed with RGF (between 300 and $375^{\circ} \mathrm{C}$ ). In general, flue gases must be cooled down before entering the dust removal system, not only in the case of using baghouse filters but also with electrostatic precipitators (ESP). A higher efficiency of particle collection is achieved in the ESP due to the reduction of particles resistivity caused by the flue gas temperature decrease [31]. Hence, flue gas temperature is reduced down to $200-220^{\circ} \mathrm{C}$, but always above dew point. At this point, flue gas heat recovery before further cleaning stages and $\mathrm{CPU}$ is mandatory in order to take advantage of this waste energy.

In this sense, considering the different systems involved in an oxy-fuel power plant, many energy integration possibilities appear. Figure 1 shows some heat recovery configurations. Figure 1a shows a typical waste energy recovery proposal for oxy-fuel combustion systems based on PC boiler technology. Flue gases are cooled and used to preheat the RFG. If additional cooling is needed before the CPU, the energy is used to preheat the LP condensate of the steam cycle. Flue gases reduce their temperature from more than $400{ }^{\circ} \mathrm{C}$ 
to less than $200{ }^{\circ} \mathrm{C}$. Then, they are dehumidified and split to the CPU and the recirculation. RFG are heated up to $375^{\circ} \mathrm{C}$ [21]. Similar layouts are found elsewhere [23-25]. Kakaras et al proposed the same idea for oxy-fuel retrofit power plants [32] but for new designed installations they included oxygen preheating with $\mathrm{CO}_{2}$ of the $\mathrm{CPU}$ and flue gases before the mixing with RFG [27]. Oxygen preheating was in two stages from 20 to $110^{\circ} \mathrm{C}$ and from 110 to $350^{\circ} \mathrm{C}$.

Other researches have proposed a different layout due to the use of CFB [4]. As it is usual in the air-fired CFB units, the large amount of material circulating within the bed allows getting a better control of the temperature inside the furnace. Some novel heat exchangers configurations have appeared during the last decades (e.g. new cyclone separators concepts [33], novel wing walls arrangements [34,35], external heat exchangers (EHE) [15] and internal fluidized bed heat exchangers (FBHE) [36]). Furthermore, the technology for the supercritical steam generation in the furnace was introduced [37]. To this extent, the combination of oxycombustion and CFB technology bring out some additional advantages regarding oxy-fuel PC power plants. It allows broader fuel flexibility, high combustion efficiency and lower levels of pollutant emissions. In this sense, in the oxy-fired CFB designs, it is usual the oxygen preheating to increase boiler efficiency and the use of EHE for fluidized bed temperature control and convective heat exchangers in flue gases. If high oxygen content is used in the CFB boiler, flue gas mass flow is reduced and as consequence, RFG is also significantly reduced. That means that the energy recovery arrangement can be modified and part of the flue gas energy content can be transferred to other subsystems. Specially, oxygen needs now to be preheated since RFG mass flow has been reduced and mixing of flows is not enough to increase $\mathrm{O}_{2}$ temperature from 20 to $250-300{ }^{\circ} \mathrm{C}$. In addition, integration with steam cycle can be different too and both, LP and HP feedwater flows can also be preheated. Figure $1 \mathrm{~b}$ shows new possibilities for energy recovery from flue gases.
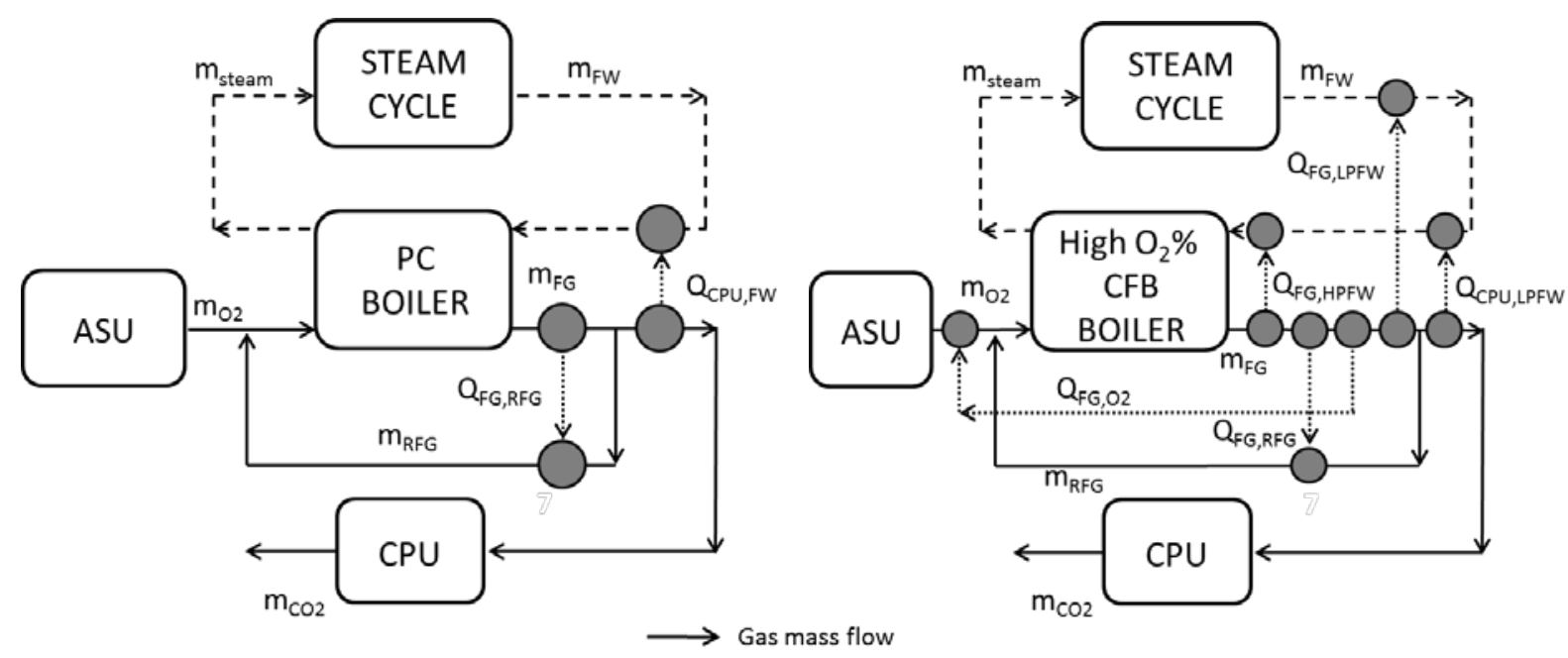

(a)

$$
\begin{aligned}
& -\rightarrow \text { Steam/water mass flow } \\
& \ldots . . . \rightarrow \text { Heat }
\end{aligned}
$$
oxy-fuel combustion systems based on high oxygen concentration CFB boilers 
Thus, different heat integration configurations for the oxy-fuel power plant involving all the subsystems could be proposed in order to increase the overall net electric efficiency and consequently, decreasing the energy penalty. Mathematically it is possible to optimize the heat exchanger network to maximize the power plant efficiency and obtain the adequate heat exchanger design and location. Previous work presented an overall net efficiency of $36.42 \%$. Nevertheless, although from a mathematic point of view this solution can be obtained, it could not be considered a feasible solution. For achieving the maximum heat recovery it is necessary to make use of a large number of heat exchangers (more than 25 in the low pressure condensate stream for a pinch value of $10^{\circ} \mathrm{C}$ ). It meant a too complex and expensive network. As a first step, mathematical process has to be stopped with a lower heat exchanger quantity (11 heat exchangers) and increasing the (low pressure) steam bleeding to compensate the heating demand. Evidently, net electric efficiency reduces but it remains in relatively high values, $36.17 \%$ [29].

In the bibliography there is a lack of critical analysis of the implications and conditions of proposed heat exchangers in an optimized design. This step is not critical when efficiency optimization is not the aim of the work. When the design tries to use as much as waste energy as possible, it is completely necessary an evaluation of the heat exchangers arrangement and the streams involved to identify some potential risks that could affect the operability of the system. In particular, for the heat recovery section of an oxy-fuel power plant (figure $1 \mathrm{~b}$ ) the potential risks include:

1. Oxygen preheating with flue gases. In general oxygen stream has a low inlet temperature (as low as $20^{\circ} \mathrm{C}$ ) which increases the possibility of acid condensation if flue gases are used for heating and it leads to the use of expensive materials.

2. Moreover, leakages from oxygen to gases side could result in a deterioration of the materials. They usually are not prepared to operate at conditions with high oxygen concentration, and it could even suppose risk in the safety operation of the power plant.

3. Pure oxygen temperature. Raising the pure oxygen stream temperature above $200^{\circ} \mathrm{C}$ could suppose safety problems.

4. Cooling flue gas stream with low pressure condensate at low temperature. Additional potential risk appears when flue gases stream is cooled down with low temperature condensate streams (below $130{ }^{\circ} \mathrm{C}$ ), since it could cause corrosion problems if acid dew point condition on flue gases side is reached.

5. The design of the flue gases-RFG (gas-gas) heat exchanger is complex. Due to the low temperature difference between hot-cold streams and their high mass flows, large equipment is required. In addition, leakages can affect final oxygen concentration in oxidant at boiler inlet, changing combustion performance and increasing furnace temperature.

Most of the potential risks with the optimized configuration are common with conventional air-fired units. However, the likely damages are increased with the presence of large quantities of pure oxygen within the oxidant flow. A new heaters configuration in presented in Figure 2. Complexity is increased regarding original configurations in Figure 1, but now some technical solutions have been taken into account in order to overcome the main 
limitations of the previous optimized layout. Some of the solutions that have been applied are the following:

1. Oxygen could be heated, firstly, by a stream fraction of the low pressure feed stream, and secondly by an indirect heat exchange with flue gases stream until $190^{\circ} \mathrm{C}$ preventing high oxygen temperatures. With this modification the two stage oxygen preheating avoids the use of flue gases for very low temperature oxygen heating (potential risk 1), and consequently, there is no potential corrosion risk because of acid condensation in flue gases side (potential risk 1). High temperatures in oxygen (problem 3 ) and leakages to flue gases side are also avoided (potential risk 2). Then oxygen could be mixed with RFG and increase its temperature by additional heating in SCAH (Steam Coil Air Heater). For this purpose, steam from high pressure bleeding could be used. With this configuration, it is not necessary oxygen preheating with high temperature flue gases and there is plenty of energy for heating high pressure feedwater stream.

2. Flue gases stream to CPU unit is cooled with an additional heat exchanger, with low pressure condensate stream. This last heat exchanger could imply a corrosion risk if inlet condensate temperature is low. Thus, to remove any potential risk and avoid any damage in the heater, a plastic heat exchanger should be considered.

3. With the new configuration there are no flue gases-RFG (gas-gas) heat exchangers avoiding any risk/problems associated with this equipment.

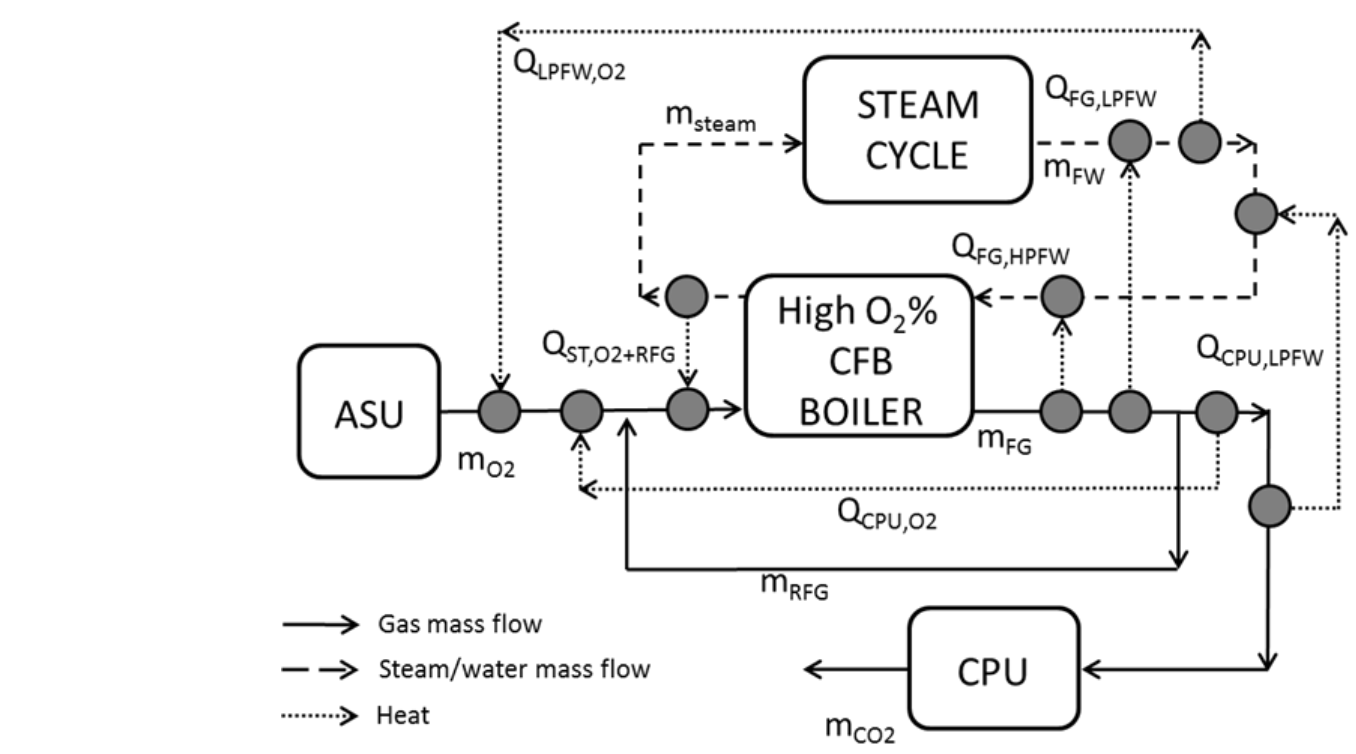

Fig.2 Heat recovery configuration from flue gases with solutions to overcome potential risks for high oxygen concentration CFB power plants

Once the functional configuration is defined it is mandatory to extend the analysis to the complete power plant in order to obtain the net electric efficiency and compare it with the previous optimized schemes. It is presumed that the power plant efficiency is going to be lower but with the proposed solution, some potential risks have been avoided just with commercial and available technology. 


\section{Evaluation}

299 In a previous work about the design of a second generation oxy-fuel power plant, flue gas 300 from oxy-CFB combustion was cooled in the heat recovery area in five heat exchangers [29]. 301 The first one to take advantage of highest temperature, flue gases exchanged energy with a $\mathrm{HP}$ feedwater heater from steam cycle, reducing the temperature from $331{ }^{\circ} \mathrm{C}$ to $284{ }^{\circ} \mathrm{C}$, figure $1 \mathrm{~b}$. Then, two heat exchangers were used to heat the RFG and oxygen preheating. Flue gases reduced their temperature to around $220{ }^{\circ} \mathrm{C}$ and oxidant (RFG + Oxygen) was heated to $260{ }^{\circ} \mathrm{C}$. Before recirculation, the temperature of the flue gases was reduced to 140 ${ }^{\circ} \mathrm{C}$ with a low pressure heater. An additional heat exchanger was needed before the CPU to reduce gas temperature to $25^{\circ} \mathrm{C}$.

As it was presented, due to the above described risks and in order to be able to select commercially feasible materials for heat exchangers and flue gas ductwork, the concept of heat integration is modified making use of both Pinch methodology and Aspen Plus simulations. The objective, again, is the minimization of the energy penalty associated to the carbon capture in the oxy-CFB power plant but with an operational, safe and flexible configuration of the plant. The process configuration includes the following heat exchangers, previously described in Figure 2:

- Gas to water heater $\left(\mathrm{Q}_{\mathrm{FG}, \mathrm{HPFW}}\right)$ : preheating of HP feedwater. Flue gases reduce their temperature from 325 to $232{ }^{\circ} \mathrm{C}$ for heating up a portion of high pressure feedwater that is located in parallel to the common layout (Figure 4). Compared to the usual HP feedwater preheating, the new HP heater arrangement is now parallel to the HP feedwater preheaters which allows more heat extraction from flue gas and reduces steam extractions to obtain more net power output in steam turbine.

- Gas to water heater $\left(Q_{F G, L P F W}\right)$ : preheating of condensate stream. The cold inlet temperature to the heater is controlled equal or higher than $130{ }^{\circ} \mathrm{C}$ which has, according to the measurements, pointed out to be high enough in order to avoid acid dew point corrosion in flue gas side. Flue gas is cooled down to $200{ }^{\circ} \mathrm{C}$ before the baghouse filters. High recycled gas temperature after the ID and RFG fans $\left(225^{\circ} \mathrm{C}\right)$ allows elimination of the RFG preheater before mixing with pure oxygen.

- Water to oxygen heater $\left(Q_{L P F W, O 2}\right)$ : it is the first stage of oxygen preheating from ASU. The use of flue gases is avoided for low temperature oxygen heating and also leakages and the potential corrosion risk due to acid condensation in flue gases side. LP condensate flow from the steam cycle is used as the heating media. Energy from water is exchanged to oxygen and then the condensate is returned back cooled at $140{ }^{\circ} \mathrm{C}$. In the matter of fact, major part of the heat extracted in LP Eco is transferred indirectly to oxygen. However, a new situation arises when gas-water heaters are used in the LP condensate section. It is mandatory to overcome the $130{ }^{\circ} \mathrm{C}$ limitation for cold temperature. Figure 3 shows the concept developed in order to solve efficiently this issue avoiding corrosion risk potential at the same time. 


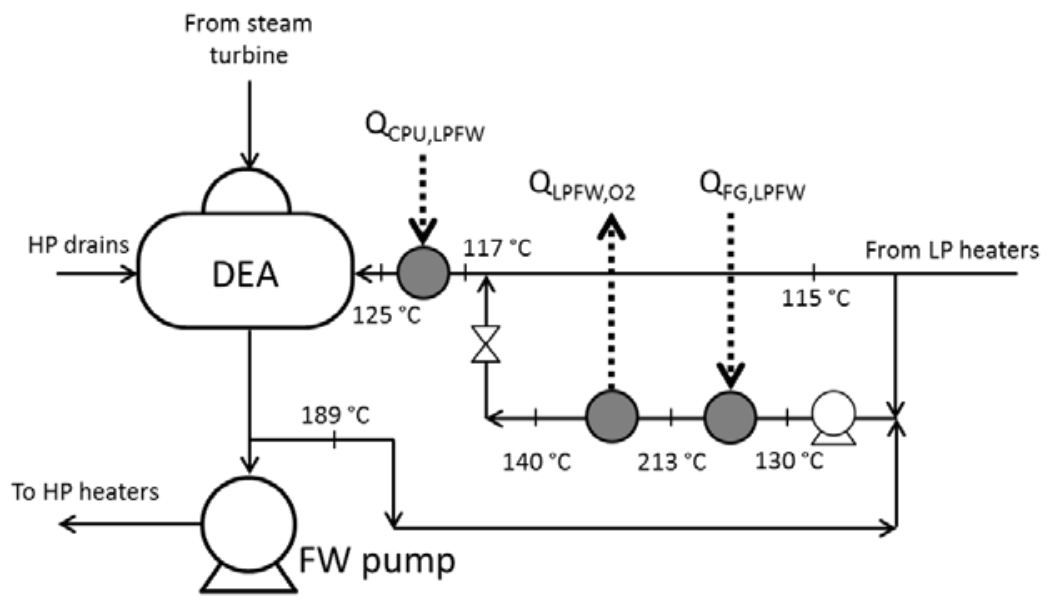

Fig.3 Novel heat recovery integration flue gases-LP feedwater for corrosion avoiding

A small fraction from the main flow is extracted from the feedwater tank after deaerator (about $1 \%$ of the total mass flow, $189^{\circ} \mathrm{C}$ ). Then it is mixed with part of the $\mathrm{LP}$ condensate flow in order to achieve $130{ }^{\circ} \mathrm{C}$ before entering $\mathrm{Q}_{\mathrm{FG}, \mathrm{LPFW}}$ heater. Flue gases temperature can be now reduced down to the temperature limitation of the baghouse filters system $\left(200{ }^{\circ} \mathrm{C}\right)$ by increasing LP condensate temperature. As consequence, a water-oxygen heat exchanger can be added taking advantage of the $213{ }^{\circ} \mathrm{C}$ condensate flow temperature. This is the first stage of $\mathrm{O}_{2}$ preheating $\left(\mathrm{Q}_{\mathrm{LPFW}, \mathrm{O} 2}\right)$. An additional pump must be installed for pressure increasing in order to avoid water evaporation when temperature is raised.

- Gas to water $\left(Q_{C P U, L P F W}\right)$ : it is the final stage of heat extraction from the flue gas before entering the flue gas condenser. Flue gases stream to CPU unit is cooled from $182{ }^{\circ} \mathrm{C}$ to $127{ }^{\circ} \mathrm{C}$ with low pressure condensate stream just before deaerator (see figure 3 ). This last heat exchanger could imply a corrosion risk since inlet condensate temperature is $117^{\circ} \mathrm{C}$. Thus, to remove any potential risk and avoid any damage in the heater, a plastic heat exchanger should be considered. This kind of technology is already available and it is common in the boiler cold-end of large supercritical units for diminishing flue gas temperature below dew point $\left(90-85^{\circ} \mathrm{C}\right)$ [38].

- Gases to water to oxygen $\left(\mathrm{Q}_{\mathrm{CPU}, \mathrm{O} 2}\right)$ : it is the second stage of oxygen preheating. Indirect heat exchanger concept is used to avoid acid dew point in the flue gas side surfaces due to cold oxygen. Also, oxygen leakage into the flue gas duct is avoided in the event of tube failure. Oxygen is preheated from $138^{\circ} \mathrm{C}$ to $190^{\circ} \mathrm{C}$ before mixing it with RFG. Flue gas is cooled from $209^{\circ} \mathrm{C}$ down to $182{ }^{\circ} \mathrm{C}$ before the final cooling stage upstream the $\mathrm{FG}$ condenser. Figure 4 shows a schematic view of the indirect heat exchanger concept for the second stage of the oxygen preheating. An additional auxiliary steam heater has been included for temperature control. 


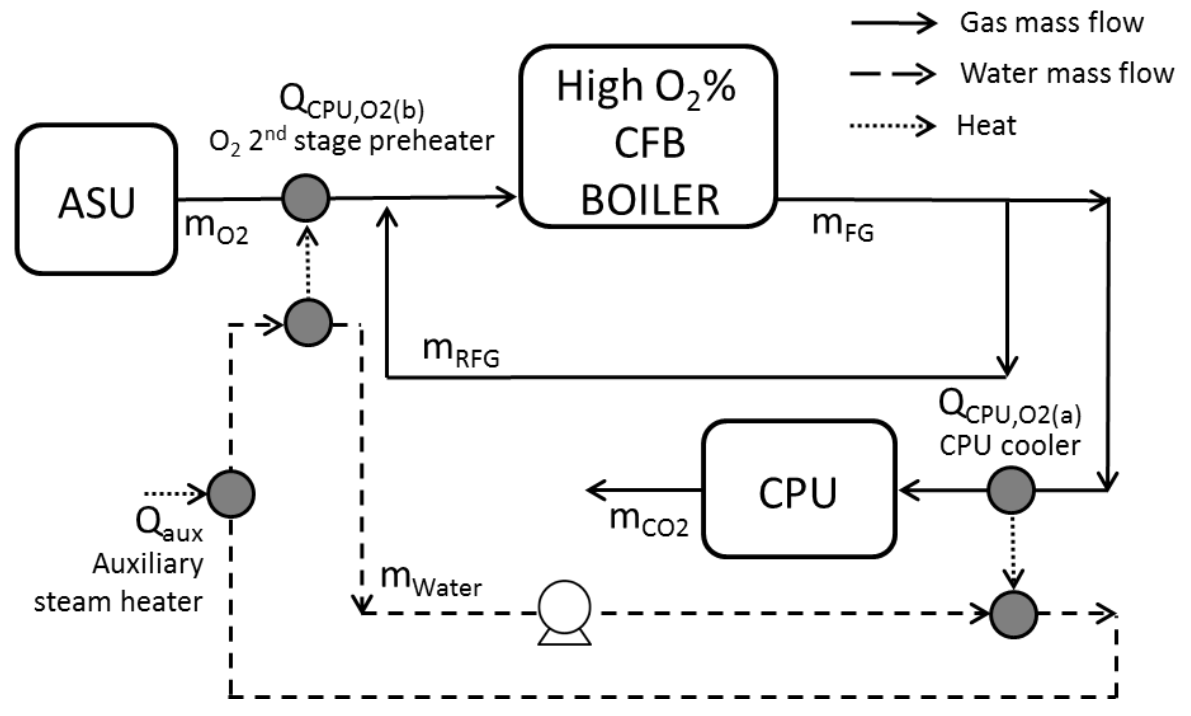

Fig.4 Indirect heat exchanger concept for the second stage of oxygen preheating

- Steam Coil Air Heaters ( $\left.\mathrm{Q}_{\mathrm{ST}, \mathrm{O} 2+\mathrm{RFG}}\right)$ : SCAHs are applied for preheating primary and secondary oxidant. After mixing oxygen and flue gases streams, temperature is around $215^{\circ} \mathrm{C}$. Steam for SCAHs is extracted from one of the high pressure bleeds of the steam turbine at $350.5^{\circ} \mathrm{C} / 56.7$ bar. The condensate from SCAHs is returned in saturated state $189.4{ }^{\circ} \mathrm{C} / 12.4$ bar to the deaeration tank. The final oxidant temperature $\left(262{ }^{\circ} \mathrm{C}\right)$ is approximately $10^{\circ} \mathrm{C}$ below bleeding saturation temperature.

Figure 5 shows the complete concept for the high oxygen concentration oxy-fuel CFB power plant. The data of reference power plant were already presented in [29] and they main ones are also collected in Table 2. Within this scheme all the modifications regarding flue gas waste heat integration have been included and in addition, ASU and CPU energy flows have been also considered and integrated according to streams temperature level with the steam cycle. By applying this final power plant design it is possible use lower cost proven materials in heat exchangers and simple equipment designs avoiding gas-gas heaters. Simultaneously we are capable to mitigate availability issues associated in the flue gas cooling. After the implementation of the proposed modifications, the best feasible configuration for the oxyfuel power plant is achieved. 


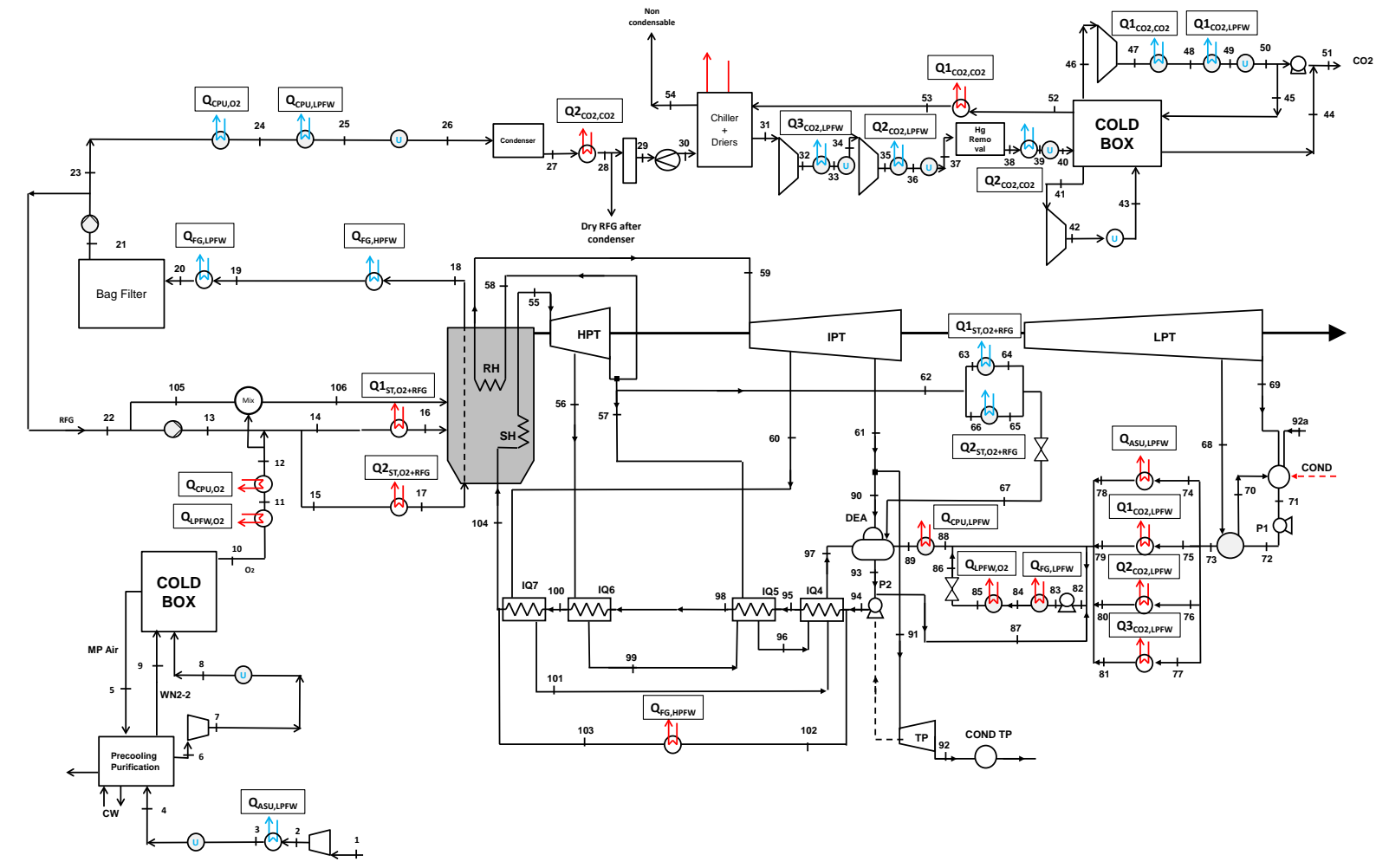

Fig.5 Complete heat integration scheme for the operational oxy-fuel CFB power plant concept

Once the configuration was defined, it was modelled in Aspen Plus. After integration, some cooling requirements remain in ASU and CPU since no integration chances are allowed due to temperature levels. They are represented in Figure 5 as utilities (symbol U). Table 1 collects the main parameters of the total heat exchanger network, including inlet and outlet hot and cold streams temperature (Hot $\mathrm{T}_{\text {in-out }}\left[{ }^{\circ} \mathrm{C}\right]$, Cold $\mathrm{T}_{\text {in-out }}\left[{ }^{\circ} \mathrm{C}\right]$ ), the transferred heat ( $\mathrm{Q}$ $[\mathrm{kW}])$ and the heat exchanger type used for each case.

Table 1. Heat exchangers main parameters

\begin{tabular}{|c|c|c|c|c|c|c|}
\hline HEX & $\mathrm{Q}[\mathrm{kW}]$ & $\begin{array}{c}\text { Hot } \\
\text { stream }\end{array}$ & $\begin{array}{c}\text { Hot } \\
\mathrm{T}_{\text {in-out }}\left[{ }^{\circ} \mathrm{C}\right]\end{array}$ & $\begin{array}{l}\text { Cold } \\
\text { stream }\end{array}$ & $\begin{array}{c}\text { Cold } \\
\mathrm{T}_{\text {in-out }}\left[{ }^{\circ} \mathrm{C}\right]\end{array}$ & Type \\
\hline $\mathrm{Q}_{\mathrm{FG}, \mathrm{HPFW}}$ & 47777 & FG & $325-232$ & HP FW & $196-299$ & Shell and tube \\
\hline $\mathrm{Q}_{\mathrm{FG}, \mathrm{LPFW}}$ & 15884 & $\mathrm{FG}$ & $232-200$ & LP FW & $130-213$ & Shell and tube \\
\hline $\mathrm{Q}_{\mathrm{LPFW}, \mathrm{O2}}$ & 14018 & LP FW & $213-140$ & $\mathrm{O}_{2}$ & $20-138$ & Shell and tube \\
\hline $\mathrm{Q}_{\mathrm{CPU}, \mathrm{O2}}$ & 6337 & CPU gas & 209-182 & $\mathrm{O}_{2}$ & $138-190$ & Indirect HEX \\
\hline $\mathrm{Q}_{\mathrm{CPU}, \mathrm{LPFW}}$ & 12238 & CPU gas & $182-127$ & LP FW & $117-125$ & Plastic HEX \\
\hline $\mathrm{Q} 1_{\mathrm{ST}, \mathrm{O} 2+\mathrm{RFG}}$ & 11235 & Steam & $350-250$ & $\mathrm{O}_{2}+\mathrm{RFG}$ & $211-262$ & $\mathrm{SCAH}$ \\
\hline $\mathrm{Q} 2_{\mathrm{ST}, \mathrm{O} 2+\mathrm{RFG}}$ & 6472 & Steam & $350-250$ & $\mathrm{O}_{2}+\mathrm{RFG}$ & 211-262 & SCAH \\
\hline $\mathrm{Q}_{\text {ASU,LPFW }}$ & 45579 & Air & $143-60$ & LP FW & $50-115$ & Shell and tube \\
\hline $\mathrm{Q}_{\mathrm{CO} 2, \mathrm{LPFW}}$ & 28656 & $\mathrm{CO}_{2}$ & $203-60$ & LP FW & $50-115$ & Shell and tube \\
\hline Q2 ${ }_{\mathrm{CO} 2, \mathrm{LPFW}}$ & 16341 & $\mathrm{CO}_{2}^{(1)}$ & $156-60$ & LP FW & $50-115$ & Shell and tube \\
\hline $\mathrm{Q}_{\mathrm{CO}, \mathrm{LPFW}}$ & 15260 & $\mathrm{CO}_{2}^{(1)}$ & $160-62$ & LP FW & $50-115$ & Shell and tube \\
\hline $\mathrm{Q} 1_{\mathrm{CO} 2, \mathrm{CO} 2}$ & 993 & $\mathrm{CO}_{2}$ & $208-203$ & $\mathrm{CO}_{2}^{(2)}$ & $23-70$ & Shell and tube \\
\hline $\mathrm{Q} 2 \mathrm{CO} 2, \mathrm{CO} 2$ & 1596 & $\mathrm{CO}_{2}{ }^{(1)}$ & $48-37$ & $\mathrm{CO}_{2}^{(3)}$ & $25-34$ & Shell and tube \\
\hline
\end{tabular}


${ }^{(1)}$ not pure $\mathrm{CO}_{2}(89 \%$ vol. $) ;{ }^{(2)}$ not pure $\mathrm{CO}_{2}(34 \%$ vol. $) ;{ }^{(3)}$ not pure $\mathrm{CO}_{2}(85 \%$ vol. $)$

In Table 2, the final simulation results obtained for the new boiler heat integration concept (operational HEN) are compared with the results based on the first generation oxy-fuel reference power plant (oxy-fuel reference), the mathematical optimized boiler configuration (optimized HEN) and the modified optimized configuration with the reduced number of heaters (feasible HEN). The net electric efficiency was slightly lower compared to mathematical optimized second generation. As consequence, the energy penalty increased a small percentage.

Table 2. Comparison of electric generation results and efficiency penalty reduction

\begin{tabular}{|l|c|c|c|c|}
\hline & $\begin{array}{c}\text { Oxy-fuel } \\
\text { reference }\end{array}$ & $\begin{array}{c}\text { Optimized } \\
\text { HEN }\end{array}$ & $\begin{array}{c}\text { Feasible } \\
\text { HEN }\end{array}$ & $\begin{array}{c}\text { Operational } \\
\text { HEN }\end{array}$ \\
\hline $\mathrm{O}_{2}$ content (\%vol.) & 25.0 & 40.0 & 40.0 & 40.0 \\
\hline Boiler input (LHV, MW) & 1561.0 & 1561.0 & 1561.0 & 1574.8 \\
\hline Boiler efficiency (LHV, \%) & 90.0 & 93.0 & 93.0 & 91.4 \\
\hline Gross electric power (MW) & 690.3 & 745.1 & 741.2 & 736.0 \\
\hline Gross electric efficiency (\%) & 44.23 & 47.73 & 47.48 & 46.73 \\
\hline Net electric power (MW) & 513.8 & 568.5 & 564.6 & 564.2 \\
\hline Net electric efficiency (\%) & 32.91 & 36.42 & 36.17 & 35.83 \\
\hline Efficiency points penalty ${ }^{(1)}$ & 10.54 & 7.03 & 7.28 & 7.62 \\
\hline
\end{tabular}

(1) Air-fired reference power plant data: net electric efficiency, 43.45\%; gross electric power, 705.7MW; net electric power, 672.5MW

462

463

464

465

466

467

468

469

470

471

472

473

474

475

476

477

478

479

480

481

482

The increase of the $\mathrm{O}_{2}$ concentration in the oxidant flow is achieved by means of reducing the RFG percentage. Consequently, total energy losses regarding flue gas are also reduced and boiler efficiency increases in comparison with reference oxy-fuel power plant. Boiler efficiency calculation in the last case differs from previous cases because of energy from the steam cycle is now being used to heat the oxidant flow and as a result, the boiler heat input is increased. In any case, net electric efficiency and energy penalty can be used to compare the four power plant configurations. The net electric efficiency of the operational power plant concept is $35.83 \%$ and the energy penalty is 7.6 , just 0.34 efficiency points higher than the feasible HEN case. However, a configuration that avoids potential risks and operational problems has been now designed with a minor efficiency loss regarding optimized cases.

\section{Conclusions}

Oxy-fuel combustion appears as a promising technology for $\mathrm{CO} 2$ capture but the reduction of the net electric efficiency of power plants in 10-12 efficiency points becomes unacceptable. Therefore, the energy penalty associated mostly with additional auxiliary power of the gas systems (ASU, CPU) is considered one of the main drawbacks concerning CCS technologies deployment. In order to increase the interest in CCS and facilitate the economic feasibility of the processes, it is mandatory to reduce the energy penalty as much as possible. 
In this sense, novel concepts are being developed. The second generation oxy-fuel CFB power plant aims at using of high oxygen concentration in the boiler (up to $40 \%$ vol.) to increase the boiler efficiency. The combination of both technologies, high oxygen level and CFB, increases the heat integration possibilities between subsystems and the design of new heaters networks arrangements. Hence, waste energy recovery turns into mandatory in order to improve the overall power plant efficiency by reducing the energy penalty. Many solutions have tried to show a significant increase in power plant efficiency but practical proposals are necessary to develop the technology.

494

495

A comparison between different energy integration approaches has been carried out starting from an oxy-fuel reference power plant. In a previous step, a heat integration methodology based on pinch analysis together with Aspen Plus modelling was developed and applied to second generation oxy-fuel CFB power plant concept. Results showed an important increase in power plant net efficiency and a remarkable energy penalty reduction. However, it had to be defined a new feasible concept in order to reduce the total number of heaters and to look for a balance between efficiency optimization and complexity. Further research has tried to include a practical and operational approach for the heat exchanger network design. Some potential risks have been detected, especially when gas-gas heaters are used and low temperatures $\left(<130^{\circ} \mathrm{C}\right)$ are reached in the heater. In these cases, the possibility of acid condensation increases if flue gases are used for heating and it leads to the use of expensive materials. Moreover, leakages from one side to another of the heater could result in a deterioration of the materials since they are not prepared to operate at conditions with high oxygen concentration.

With the aim of overcoming these potential problems, an operational HEN design is proposed. Applied solutions try to use lower cost proven materials in heat exchangers and simple equipment designs avoiding gas-gas heaters. Novel arrangements are presented, such as indirect heat exchangers, plastic heaters or different configurations integrating high pressure feedwater and low pressure condensate mass flows. The final CFB oxy-fuel power plant concept is modelled and results are compared with previous optimized solutions. The net electric efficiency of the operational power plant concept is $35.83 \%$ and the energy penalty is 7.6, just 0.34 efficiency points higher than the feasible HEN case. Comparing with the oxy-fuel reference power plant, the net electric efficiency is increased about 3 points and

\section{Acknowledgements}

520 The research leading to these results has received funding from the European Community's 521 Seventh Framework Programme (FP7/2007-2013) under grant agreement number 295533 O2GEN Optimization of oxygen-based CFBC technology with $\mathrm{CO}_{2}$ capture

\section{References}

525 [1] J. D. Figueroa, T. Fout, S. Plasynski, H. Mcllvried, R. D. Srivastava. Advances in $\mathrm{CO}_{2}$ capture 526 technology - The U.S. Department of Energy's Carbon Sequestration Program, International Journal of Greenhouse Gas Control 2 (2008) 9-20. 

Santos. Oxyfuel combustion for $\mathrm{CO} 2$ capture in power plants, International Journal of Greenhouse Gas Control 40 (2015) 55-125.

533

[3] E. J. Anthony. Oxyfuel CFBC: status and anticipated development, Greenhouse Gases

[4] M. Weng, C. Günther, A. Kather. Flue gas concentrations and efficiencies of a coal-fired oxyfuel power plant with circulating fluidised bed combustion, Energy Procedia 37 (2013) 1480-1489.

[5] B. Leckner, A. Gómez-Barea. Oxy-fuel combustion in circulating fluidized bed boilers, Applied Energy 125 (2014) 308-318.

[6] S. Seddighi, D. Pallarès, F. Normann, F. Johnsson. Progress of combustion in an oxy-fuel circulating fluidized-bed furnace: measurements and modeling in a $4 \mathrm{MWth}$ boiler, Energy Fuels 27 (2013) 6222-6230.

[7] Y. Tan, L. Jia, Y. Wu, E. J. Anthony. Experiences and results on a $0.8 \mathrm{MWth}$ oxy-fuel operation pilot-scale circulating fluidized bed, Applied Energy 92 (2012) 343-347.

[8] T. Czakiert, K. Sztekler, S. Karski, D. Markiewicz, W. Nowak. Oxy-fuel circulating fluidized bed combustion in a small pilot-scale test rig, Fuel Processing Technology 91 (2010) 16171623.

[9] L. Duan, C. Zhao, W. Zhou, C. Qu, X. Chen. Effects of operation parameters on NO emission in an oxy-fired CFB combustor, Fuel Processing Technology 92 (2011) 379-384.

[10] L. M. Romeo, R. Kuivalainen, J. P. Tranier, M. Gómez, A. Sánchez-Biezma, A. Tourunen, 559 B. Navarrete, J. L. Bayort, P. Gimondo, R. Bialecki, T. Hyppänen. Optimization of oxygenbased CFBC technology with $\mathrm{CO} 2$ capture (O2GEN). $3^{\text {rd }}$ Oxyfuel Combustion Conference, Ponferrada, Spain, September 2013. IEA Greenhouse Gas R\&D Programme.

[11] J. Saastamoinen. Effect of oxygen concentration and reaction order on char inventory in fluidized bed combustion, Combustion and Flame 171 (2016) 211-222.

[12] J. Lappalainen, A. Tourunen, H. Mikkonen, M. Hänninen, J. Kovács. Modelling and dynamic simulation of a supercritical, oxy combustion circulating fluidized bed power plant concept - Firing mode switching case, International Journal on Greenhouse Gas Control 28 (2014) 11-24.

[13] T. Pikkarainen, J. Saastamoinen, H. Saastamoinen, T. Leino, A. Tourunen. Development of 2nd Generation oxyfuel CFB technology - Small scale combustion experiments and model 
603

604

605

606

607

608

609

610

611

612

613

614

615

616

617

618

619 620

[14] I. Bolea, L. M. Romeo, D. Pallarès. Heat transfer in the external heat exchanger of oxyfuel fluidized bed boilers, Applied Thermal Engineering 66 (2014) 75-83.

[15] I. Bolea, L. M. Romeo, D. Pallarès. The role of external heat exchangers in oxy-fuel circulating fluidized bed, Applied Energy 94 (2012) 215-223.

[16] S. S. Khavidak, D. Pallarès, F. Normann, F. Johnsson, V. Ylä-Outinen. Heat transfer in a 4MWth circulating fluidized bed furnace operated under oxy-fired and air-fired conditions: Modeling and measurements, International Journal of Greenhouse Gas Control 37 (2015) 264-273.

[17] N. Perrin, R. Dubettier, F. Lockwood, J-P. Tranier, C. Bourhy-Weber, P. Terrien. Oxycombustion for coal power plants: Advantages, solutions and projects, Applied Thermal Engineering 74 (2015) 75-82.

[18] J-P. Tranier, R. Dubettier, A. Darde, N. Perrin. Air Separation, flue gas compression and purification units for oxy-coal combustion systems, Energy Procedia 4 (2011) 966-971.

[19] K. Goto, K. Yogo, T. Higashii. A review of efficiency penalty in a coal-fired power plant with post-combustion CO2 capture, Applied Energy 111 (2013) 710-720.

[20] B. Metz, O. Davidson, H. de Coninck, M. Loos, L. Meyer (Eds.) IPCC, 2005 - Chapter 3 Capture of CO2, Cambridge University Press, UK (2005).

[21] M. Liszka, A. Ziebik. Coal-fired oxy-fuel power unit - Process and system analysis, Energy 35 (2010) 943-951.

[22] H. Gao, A. Runstedtler, A. Majeski, R. Yandon, K. Zanganeh, A. Shafeen. Reducing the recycle flue gas rate of an oxy-fuel utility power boiler, Fuel 140 (2015) 578-589.

[23] K. Yan, X. Wu, A. Hoadley, X. Xu, J. Zhang, L. Zhang. Sensitivity analysis of oxy-fuel power plant system, Energy Conversion and Management 98 (2015) 138-150.

[24] W. Luo, Q. Wang, J. Guo, Z. Liu, C. Zheng. Exergy-based control strategy selection for flue gas recycle in oxy-fuel combustion plant, Fuel 161 (2015) 87-96.

[25] H. Hagi, Y. Le Moullec, M. Nemer, C. Bouallou. Performance assessment of first generation oxy-coal power plants through an exergy-based process integration methodology, Energy 69 (2014) 272-284.

[26] I. Hadjipaschalis, G. Kourtis, A. Poullikkas. Assessment of oxyfuel power generation technologies, Renewable and Sustainable Energy Reviews 13 (2009) 2637-2644.

[27] E. Kakaras, A. Koumanakos, A. Doukelis, D. Giannakopoulos, I. Vorrias. Oxyfuel boiler design in a lignite-fired power plant, Fuel 86 (2007) 2144-2150. 

advantages, innovative solutions and key projects, Energy Procedia 37 (2013) 1389-1404. Minimization of $\mathrm{CO} 2$ capture energy penalty in second generation oxy-fuel power plants, Applied Thermal Engineering 103 (2016) 274-281.

[30] J. Kotowicz, A. Balicki. Enhancing the overall efficiency of a lignite-fired oxyfuel power plant with CFB boiler and membrane-based air separation unit, Energy Conversion and Management 80 (2014) 20-31.

[31] B-Y. Guo, A-B. Yu, J. Guo. Numerical modeling of electrostatic precipitation: effect of gas temperature, Journal of Aerosol Science 77 (2014) 102-115.

635

636

[32] E. Kakaras, A. Koumanakos, A. Doukelis, D. Giannakopoulos, I. Vorrias. Simulation of a Greenfield oxyfuel lignite-fired power plant, Energy Conversion and Management 48 (2007) 2879-2887.

639

[33] J. Koornneef, M. Junginger, A. Faaij. Development of fluidized bed combustion - An overview of trends, performance and cost, Progress in Energy and Combustion Science 33 (2007) 19-55.

[34] A. Dutta, P. Basu. An experimental investigation into the heat transfer on wing walls in a circulating fluidized bed boiler, International Journal of Heat and Mass Transfer 45 (2002) 4479-4491.

[35] L. Cheng, Y. Xia, C. Yu, Q. Wang, W. Zhang, M. Fang. Experimental study of gas-solid flow over a novel heating surface in a CFB furnace, Powder Technology 277 (2015) 74-81.

[36] T. Eriksson, V. Barišić, K. Nuortimo, T. Jäntti. Advanced utility CFB technology for challenging new solid biomass fuels, presented at Power Gen Europe 2015, Amsterdam, Netherlands, $9^{\text {th }}-11^{\text {th }}$ June, 2015.

[37] Pioneering CFB technology, Amen Foster Wheeler, July 2015.

[38] A. Hotta, A. Kettunen, J. Utt. Milestones for CFB and OTU technology. The 460 MWe Lagisza supercritical boiler. Project update, presented at Coal Gen, Milwaukee, USA, August 660 2007.

\section{Figure captions}

Heat recovery configurations from flue gases: (a) oxy-fuel combustion systems based on PC boilers, (b) oxy-fuel combustion systems based on high 666 oxygen concentration CFB boilers potential risks for high oxygen concentration CFB power plants 
667 Figure 3 Novel heat recovery integration flue gases-LP feedwater for corrosion

668 avoiding

669 Figure $4 \quad$ Indirect heat exchanger concept for the second stage of oxygen preheating

670 Figure 5 Complete heat integration scheme for the operational oxy-fuel CFB power $671 \quad$ plant concept

672

673 Table captions

674 Table $1 \quad$ Heat exchangers main parameters

675 Table 2 Comparison of simulation results and efficiency penalty reduction 